\title{
Post-Socialist Czech Education Research on Socially Disadvantaged/Roma Children and Families: Literature Review
}

\author{
Jana Obrovská \\ Masaryk University, Faculty of Education \\ Kateřina Sidiropulu Janků \\ Carinthia University of Applied Sciences, Health Sciences and Social Work
}

\begin{abstract}
The literature review analyses papers presenting results of original empirical research on the education of socially disadvantaged/Roma children and families that was conducted in the Czech Republic between 1989 and summer 2017. Our intention to elaborate this study was to make the existing research results and procedures accessible to the international scientific community, but also to support further development of the field, including disciplinary intersections and cooperation among different research institutes. After searching through seven research databases and using knowledge of the research field, 57 studies were selected for further analysis. The review study presents five research question categories focusing on the development of the selected research field, prevailing topics/themes that are researched, research settings in which the data were collected, main methodological approaches, and primary research subjects/objects. The results of our analysis pinpoint dynamic development not only in the relevant research field but also in the practice and educational policies concerned. From the methodological point of view, the slight predominance of qualitative research procedures in the field is evident. Nevertheless, there is a pervading lack of reflexivity towards the lived world of the research participants - mainly Roma children and families - and a preferred focus on macro and mezzo levels in the research scopes. The most influential published research in the field was identified, as was cross-referencing habits. In general, productivity, as well as cross-referencing culture, have developed more intensely since 2009. In conclusion, we suggest further development in both the practice of research, as well as the development of databases, so more integrative work may support tackling education inequalities in the Czech Republic.
\end{abstract}

Keywords: the Czech Republic, education, literature review, Roma children, Roma families 
86 In recent decades, Roma have become frequently contested in the media and state policies as well as lay pub discussions. ${ }^{1}$ Numerous European institutions and national governments have started to warn against the worsening situation of this significant European ethnic minority. Many Roma are trapped in social and spatial exclusion; they are strikingly impoverished, low-educated, and increasingly face discrimination in access to labor markets as well to quality education (FRA, 2012; 2016; Szalai \& Schiff, 2014). Nevertheless, for a long time in the post-socialist development of social and educational science, the topic of the Roma was not reflected as requiring special analytical attention. With the birth of the post-socialist social order, new social issues were reflected in social sciences, and the discourse of interethnic relations, where Roma were for a time somewhat invisible or the interwar medicalized discourse persisted (Schmidt, 2018), only emerged later.

\section{Roma minority in Czech and European context}

One of the first publications reflecting on the Roma living in the Czech lands was an overview volume by P. Víšek (1999). Nevertheless, this publication, focusing on the social and political aspects of the Roma minority in the Czech lands since 1945, was not based on original field research. In the European space, Roma have long been considered a target of racialized violence and oppression (Mayall, 2004; Stauber, Roni, \& Vago, 2007). In the Czech Republic, the iconic historical publication by C. Nečas (1999) introduced the topic of the Roma holocaust that took place during the Second World War. In general, there was a missing historical awareness among the Czech population of the fact that most Roma living in the Czech Republic are of Slovak Roma origin and therefore have a specific linguistic domestic situation, different from that of ethnic majority families and, in this respect, similar to immigrant families. Even though the Czech and Slovak languages are similar, they are far from the same, particularly when it comes to academic competences like proper grammar use, which plays an essential role in the education process. And that is not to mention the huge linguistic difference of the Romany language, which, despite

1 There is an ongoing discussion among the Czech social science community regarding the use of the term "Roma". Looking at the term from the emic perspective, it happens to be problematic and replaced by the offensive exonym "Gypsy", which had been dominant in the Czech lands until the 1990s, even in professional discourses. As a lived term, the denomination "Gypsy" prevails, and the term "Roma" is, on the contrary, sometimes perceived as alienating and offensive, so the lived terminology has entirely reflected the ambiguous nature of Czech-Roma relationships to the present. Moreover, discussions about othering and essentialism appear in the field (Barša, 2008; Skupnik, 2009). In this study, we henceforth use the term Roma without quotation marks, but we are aware of the complex and problematic nature of the term. The purpose of this study was not to evaluate or elaborate on use of the terms "Roma" and "socially disadvantaged". This field of meaning is under dramatic development and could serve as material for independent study. Also, discursive discussions about the term are somewhat absent in the reviewed studies. Therefore, we reflect on the terms used by individual authors, including choices that are unclear as is, in this respect, the case of some reviewed studies. More on that in section 1.2 discussing the terminology of this paper. 
often being used only as a supplementary communication means in Roma families (Červenka, 2009), contributes to a situation where parents are not fully competent in the dominant language being used in school while their linguistic competences are overlooked by teachers as they are not considered as valuable to the education process (Pastori et al., 2019). If the Roma were not recognized as structurally different, they could not be considered as deserving of unique research attention in education research. In the following years, the situation changed, partly due to EU accession processes that triggered a closer look at the issue of how ethnic minorities are treated in the Czech Republic. In recent decades, confirming the European pattern, Czech research has also reported a growing number of socially excluded localities and a persistent reproduction of the meager social status of the Roma minority across generations (GAC, 2006; 2009; 2015). Because education is considered the precondition to progress in other areas of life (housing, employment, and so on), activists and policymakers, especially in eastern European countries, have attributed blame to the high percentage of Roma students segregated to individual schools or ethnically homogeneous schools. In several European countries, including the Czech Republic, strategic litigation in favour of the Roma minority has resulted in judgements from the European Court of Human Rights criticizing national governments and their educational systems respectively, ${ }^{2}$ with education becoming one of the most debated issues concerning the Roma minority. This is evident as well in the academic discourse, where the education of Roma students/children has recently garnered increasing attention. There are many contributions to the topic framed by different, often contradictory paradigmatic/discursive positions (see, for example, Čechovská, 2014; Trubeta, 2013), defining the research problems from diverging vantage points. Despite the increasing and diversified field of literature about Roma education, there has only been one highly erudite systematic review of the topic published in English (Lauritzen \& Nodeland, 2018), while a review specifically focused on the Czech context was, at the point of elaborating this literature review, non-existent. ${ }^{3}$ This fact was essential for our motivation to conduct this literature review.

The topic of education research regarding Roma families is not new to us. While J. Obrovská's dissertation focused on interaction rituals in primary school classrooms and their role in the ethnic identity dynamics of Roma students (2018), K. Sidiropulu Jankư's long term interest lies in ethnographic research of ethnic urban marginality and methodological innovations in the analysis of interethnic relationships in Czech-Roma families (Nedbálková \& Sidiropulu Janků, 2015). Later we collaborated on the research project Inclusive Education and Social Support to Tackle Inequalities in Society (ISOTIS), which focuses on understanding and tackling education inequalities at an early age in ethnic-cultural minority or socially disadvantaged families and educatio-

2 See e.g., D.H. and others versus the Czech Republic (Council of Europe. Court of Human Rights. Grand Chamber, 2007).

3 During the review, the critical review study of Fónadová, Katrňák, and Simonová (2019) on the effect of ethnic origin on achieved education was published. 
88 nal systems in eleven European countries. When we started to cooperate with colleagues from other European countries on an international comparative study focused on parental views of the education of socially disadvantaged Roma children within the European Union, we realized that it is challenging to share relevant scientific resources based on empirical data from the Czech Republic with an international audience because most research outputs are written in Czech. The ISOTIS project is committed to critical revision of similar presuppositions, and therefore we also aim to thoroughly review the position of Roma in education research in the Czech context. We also analyse the power perspectives of the reviewed studies, trying to determine whether the research participants (Roma children, but also others such as family members or teachers) are treated merely as research objects or whether they are actively drawn into the process as its subjects, in addition to how the power relations of researchers and research participants are reflected upon. One of our primary goals is to elaborate a review reflecting the $\mathrm{Czech}$ context for the international scientific community. The only existent review on Roma education in European countries (Lauritzen \& Nodeland, 2018) states nine studies from the Czech context on Roma education published in English in the last two decades. It is important to note that with the exception of Cviklová (2015), Jarkovská, Lišková, and Obrovská (2015), and Němec et al. (2015), the remaining six studies published in English were written by authors presumably not fluent in Czech and were therefore limited in the use of contact research methods (e.g., Igarashi, 2005) and focused mainly on policy discourse comparisons (e.g., Brüggermann \& Friedman, 2017; Rostas \& Kostka, 2014). Therefore, we remained with the original plan to review exclusively studies written in the Czech language.

Original empirical Czech research on Roma education usually does not extend beyond the national/local scope. With this literature review, we hope to make the actual results accessible to a broader audience and suggest further inquiry into research trends and possible development in the field of socially disadvantaged/Roma children education based on deeper collaboration with the international community of scholars.

\subsection{Review goals and functions}

Our literature review summarizes original empirical research on the education of socially disadvantaged Roma children in the Czech Republic between 1989 and summer 2017.4 The goal of the review is to identify key topics which are crucial to the current state of knowledge in the field and contrast them with topics that seem to be at this point marginal. At the same time, we strive to reflect on the practical methodological approaches which are usually followed in this field and the ordinary objects/subjects that are the focus of researchers. Following these goals, we formulate five main research questions for the literature review on original empirical

4 To have a complete selection sample, we did not include studies published after the second half of the year 2017, despite some new relevant studies that appeared during the course of the review. 
research concerning the education of socially disadvantaged Roma children and families in the Czech Republic between 1989 and summer 2017:

1. How has the research field developed, including inner relations between authors and research institutions?

2. What current research topics/themes can be derived from the research questions formulated in the reviewed studies?

3. What are the main methodological approaches and data collection techniques in the research?

4. What are the current settings in which the data is collected?

5. Who have been the main studied subjects/objects in the research on the education of socially disadvantaged Roma children in the Czech Republic between 1989 and summer 2017?

Following J. Mareš's typology of functions, a review study can provide for the development of the research field as well as for other researchers (2013, p. 436, Table 2). We suppose that our study classifies the following: research traditions, schools, and trends; identifies critical topics and blind spots in the field; places the research into historical as well as an actual research context; constructs criteria which allows for the differentiation between important and less relevant studies; recommends directions for further research; helps to understand the research structure; provides methodological insights into the research field; and categorizes the research results in that field.

We want to identify the prevalent topics as well as the blind spots in the field from a thematic as well as a methodological point of view - which topics, methods, settings, subjects/objects are relatively marginal in current research? With our background in the discipline of sociology, we also strive to enhance interdisciplinary dialogue on the topic between scholars coming from different research fields as we have anticipated proving from the beginning of our review endeavour that the debate on the topic among authors from different disciplines is rather scarce, although the topic as such has by its nature a strong interdisciplinary character (education, special education, social education, sociology, anthropology, and ethnology are engaged in the studies). We also want to provide a critical assessment of the present research in the Czech Republic and suggestions for further development in order to enhance the comparative potential of research from the Czech context in a European scope.

\subsection{Terminology}

Before proceeding further, we will discuss the terminology used in the reviewed studies. On the one hand, the inconsistencies or ambiguities we recognize in the reviewed texts reflect the dynamic development of research and educational policies focused on the Roma in recent years, on the other hand, they also confirm the somewhat isolated approaches and procedures of individual researchers in the field. 


\subsubsection{Roma and Socially disadvantaged}

The reviewed studies use both the term Roma and socially disadvantaged, in many cases, interchangeably (e.g., in Bartoňová, 2008). The latter term was introduced legally as a reason to set up support measures (e.g., teacher assistants) for students of an ethnic minority or low-status background during reforms to the Czech education system. However, the indicators of social disadvantage have never been clearly defined, and teachers, as well as other pedagogical professionals, struggle to categorize specific students as socially disadvantaged. Although an amendment to the Education Act No. 82/2015 Coll. (Ministerstvo, 2015) brought changes in the logic of distributing support measures among students with special educational needs and disabilities, social disadvantage remains a contested term. There is an ongoing debate about what social disadvantage means, how to use the term, and how to measure it. Sometimes it is associated with the term social exclusion or socially excluded localities, which are defined, in addition to characteristics, as settlements populated with socially disadvantaged people (GAC, 2006, 2015; Hurrle et al., 2016).

The reviewed studies are not united in denominating their research subjects/objects in this respect. On closer examination, we find the reflexive approach towards the term Roma exclusively in resources written by authors with an anthropological or sociological background (Bittnerová et al. 2011; Fatková, 2013; Fónadová, 2014; Gabal \& Čada, 2010; Jarkovská et al., 2015; Kašparová \& Souralová, 2014). Only rarely did we find references to the conflicting terminologies also acknowledging the emic terms used in the research field, and this is mostly linked to researching domestic, not school settings. Thus, it can be stated that Czech education science is not in much contact with the sociological and anthropological conceptual debates on denominating the Roma and the methodological and epistemological consequences of possible choices in this respect.

\subsubsection{Practical, Special, and Segregated school}

As we mentioned in the introductory section, the Czech Republic is being criticized for the segregation of Roma students to public schools other than mainstream, especially to so-called practical schools with curricula adjusted to students with learning or behavioral disorders or mental disadvantages as well as to special schools for students with severe physical or mental handicaps or behavioral disorders. The numbers of Roma students attending special streams of public education do not statistically correspond to the distribution of mental handicaps in the population, and we can find a massive overrepresentation of Roma students in these types of schools. Another serious problem is the concentration of Roma students in ethnically and socially segregated schools, often localized in socially excluded neighborhoods. Although these schools formally follow the same Framework Educational Programme for Basic Education (Ministerstvo, 2017) as the regular basic schools, ${ }^{5}$ their curriculum is reduced, and teaching practices are adjusted to the specific needs of

5 The compulsory school education within the Czech educational system is divided into primary and lower secondary levels. The primary level is composed of five grades, while the lower secondary 
Roma students. It is good to keep these facts in mind when reading the presented literature review study.

\section{Method}

\subsection{The selection process of reviewed studies}

The selection process of the studies to be reviewed was conducted in the summer of $2017,{ }^{6}$ and consisted of several steps. Initially, we constructed five main selection criteria to search the databases: (1) the publication is based on original empirical research, (2) the data for the study was collected in the socio-spatial context of the Czech Republic, (3) the study was published in the Czech language, (4) the study was published between 1989 and summer 2017, and (5) the study deals with the education of socially disadvantaged/Roma pupils and families. Later, we formulated more specific formal as well as content selection criteria. From our list of searched publications and based on an analysis of their abstracts, we eliminated conference papers, bachelor and master's theses which did not undergo a standard anonymous peer-review process, ${ }^{7}$ and theoretical publications, as we concentrate on publications based on primary original empirical data. We then excluded publications that had a focus other than the education of socially disadvantaged Roma students.

The search was conducted in the following research databases:

- Katalog Masarykovy university Aleph (Catalogue of Masaryk University Aleph)

- Theses.cz - Vysokoškolské kvalifikační práce (Theses.cz - Repository of final theses)

- Katalog Moravské zemské knihovny (Catalogue of the Moravian Library)

- SKC CASLIN - Souborný katalog ČR (SKC CASLIN - Aggregated Catalogue of the Czech Republic)

- $\mathrm{ANL}$ - Výběr článků v českých novinách, časopisech a sbornících (ANL - Selection of Czech Print Daily News, Journals, and Proceedings)

- JIB - Jednotná informační brána (JIB - United information gate) ${ }^{8}$

- CEEOL - Central and Eastern European Online Library

In the first phase, we combined various keywords in order to find the most suitable combinations, and in this way, we determined the best combinations with the most productive results.

has four grades. Students start basic school education when six years old and should leave lower secondary school at a maximum age of 15 .

6 Therefore, only studies published before summer 2017 are included in this review study.

7 We only included post-master's and PhD dissertation theses, which, by definition, have to reach high academic standards and include original research results.

8 The operation of this database finished at the end of the year 2018 and the database knihovny. cz replaced it. These databases encompass catalogues of thousands of Czech libraries. 
Finally, we analysed the results of the following keywords, entered into search catalogues and databases, using the Boolean operator AND: ${ }^{9}$

- "Roma"

- "education" AND "Roma"

- "socially disadvantaged groups" AND "education"

- "educational inequalities" AND "ethnicity"

- "educational inequalities"

- "education" AND "ethnicity"

Apart from this, we also searched for other possibly relevant publications by authors who were already found in the catalogues/databases search.

The total number of identified publications based on the analysis of the titles was 150 , out of which, and based on the analysis of their abstracts, we selected 63 which met our selection criteria. Later on during the analysis of the whole texts, we decided to eliminate another six publications (one publication included data which was analysed in another publication by the same author; ${ }^{10}$ the second did not focus specifically on the education of socially disadvantaged Roma students; the third, as well as the fourth one, had rather theoretical focuses; the fifth focused on socially disadvantaged students, however, not on Roma specifically; and the last one used special education diagnostic methods). The final number of studies in our sample is 57 in total. In order to detect the formal as well as the content characteristics of the original list of publications, we first analyse the abstracts. In the second step of the analytical process, we analyse full publications thoroughly in order to identify (1) development of the field aimed at inter-references among the publications - in other words, if and to what extent the author(s) of the selected publication refer to other (older) publications from our list; (2) the research design (qualitative, quantitative versus mixed-methods research designs), including the methodology and methods (e.g., ethnography, case study, interview, observation); ${ }^{11}$ (3) the subject/object of the research (e.g., teachers, parents, students, NGO professionals, teacher assistants); (4) the research setting (e.g., NGO, home setting); and (5) the main research questions.

9 In most databases, we entered the combinations of keywords both in Czech and English languages. We entered the combinations only in the Czech language in the Catalogue of final theses and ANL database as these primarily encompass resources published in the Czech language. We further entered the combinations only in the Czech language in the CEEOL database as we are focused on publications published in Czech journals, and the keywords entered in English brought only English-written results.

10 J. Mareš (2013) notices that it is a frequent mistake of research literature reviews to count several publications based on the same data set. We faced such a challenge, for example, with the work of M. Levínská (2013). The author used data obtained from three Roma female respondents that were utilized in a more comprehensive book (Bittnerová et al., 2011), and so we decided to include the book instead.

11 Reflecting the fact that in most of the reviewed studies no consistent methodological approach (such as ethnography, case study, phenomenology) was systematically followed and only partial methods (such as interview, observation) were applied, we gather methodologies and methods into one analytical category for the review. Nevertheless, we reflect on the difference between methods and methodologies in Section 3.3. 
We want to stress that by following these search/analytical steps, we constructed a specific sample of publications which does not represent the complete list of texts published so far on the topic in the Czech language. There is a considerable number of closely related monographs and other studies which either did not fulfil the criteria of being based on primary empirical data; dealt with pedagogical-psychological diagnostics, interventions, or methodical/didactical processes without coherent evaluations based on primary data; or presented their research results in a format which is not standard for scientific publications (e.g., case interpretations without the rigor typical of case studies). We are also aware of the methodological limitations of searching through the selected databases as these sometimes omit some (even critical) results which do not fit the specific combinations of keywords entered in the databases (e.g. , we received a publication by GAC, 2009 as the result of database searches, but we did not receive similarly relevant publications by GAC, 2006; GAC, 2010; and GAC, 2015, which we decided to add to our list of analysed publications). We are also aware of the limited number/character of databases involved in the selection procedure. We did not include any field-specific database (e.g., for Czech research in education, it would be https: //www.npmk.cz/knihovna) as we consider the character of this research topic multidisciplinary. At the same time, many of the reviewed Czech journals are indexed in the database CEEOL, which was also the reason we included this specific database. In conclusion, the list of publications we analysed is inevitably selective and does not have the ambition to represent a comprehensive/systematic review of studies on the education of socially disadvantaged Roma students published in the Czech Republic from 1989 until today. At the same time, it does safely introduce the international audience to all the original empirical research accessible in the databases within the given timeframe and presents an elaboration of methodological scope, as well as mutual relationships between studies, authors, and research institutes.

\subsection{Analysis of the studies}

In order to facilitate such extensive analytical work, we used Atlas.ti, version 7.0 to analyse the studies, focusing on the methodological aspects (nature of the research, methods used, subject/object outline of the research, research setting, and research questions). With this focus, we coded all relevant parts of the texts covering the focused aspects explicitly. To analyse the publications selected for this study, we developed a coding tree combining inductive and deductive coding strategies. In the first run, we invented a coding tree based on categories that we assume to be taken for granted (e.g., quantitative versus qualitative versus mix methods design to identify the primary methodological approach). Later, we revised the coding tree with newly emerging categories inductively derived from the analytical work as such (e.g. , officials as a code representing the subject/object coding family). Finally, we arrived at a total number of 114 codes divided into five code families (including the analysis of research questions). Some of the codes were not used in the end for 
94 the analysis of the final set of analysed studies but were kept in the coding tree because they are part of the hermeneutic map of meanings that create the final analysis and interpretation.

\section{Results}

\subsection{Development of the research field}

When we launched the database search, we learned that the first text with original education research on the topic in the post-socialist period was written in 2002, and the first year with numerous outputs was 2007 (Figure 1).

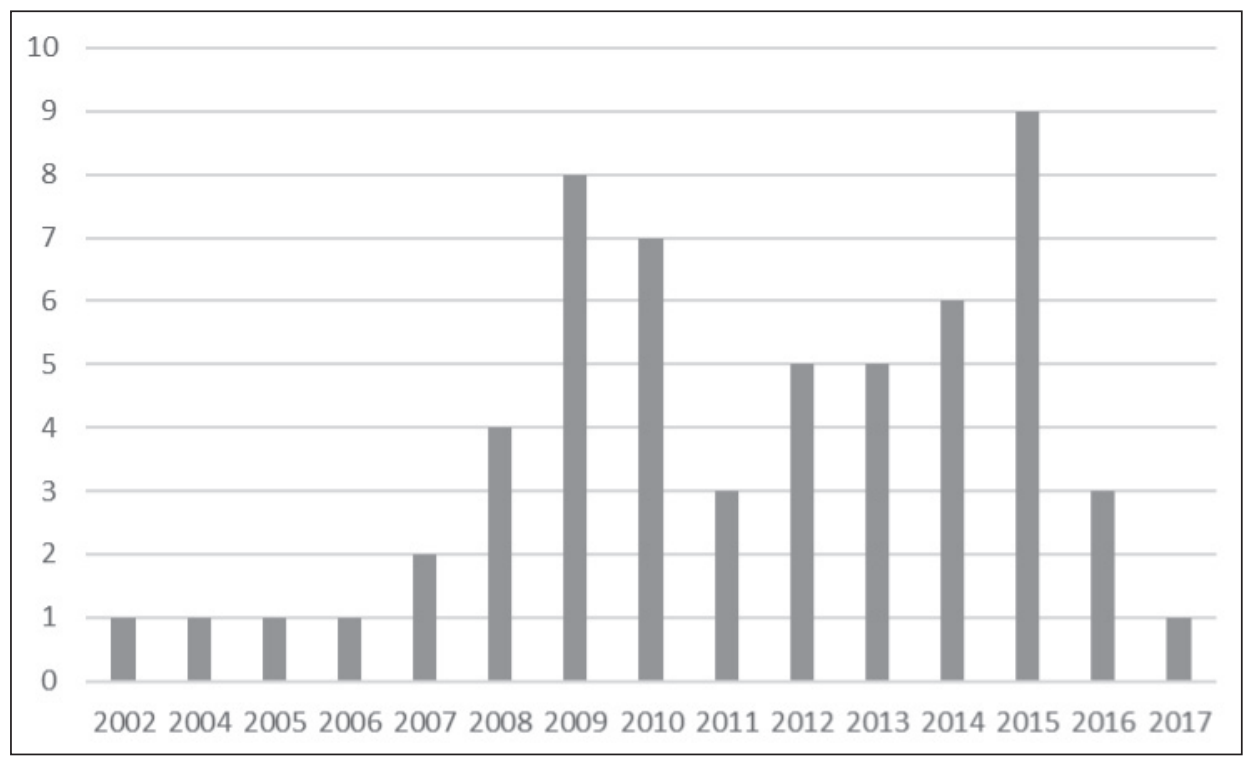

Figure 1 Number of reviewed studies published between 2002 and summer 2017

These findings follow general trends in the area of social research focused on issues associated with the Roma in the Czech Republic. The first overview of socially excluded localities requested by the Czech Ministry of Labour and Social Affairs was published in 2006 (GAC) and state-funded qualitative research on such localities appeared first in 2008 (Kašparová et al.). It seems that Roma-related issues had not been recognized as a research topic before then.

The following analysis elaborates the issue closer as we analyse and cluster the number of cross-references in the reviewed texts. A total amount of 22 studies out of 57 analysed texts do not refer to any of the published available studies that we analysed at the time, and only two studies refer to more than 20 per cent of the analysed texts available at the point of their publication, with a maximum rate of 
28 per cent. That is to say, the general habit of cross-referencing to the existing field of knowledge is, based on the analysis of chosen studies, not very common in Czech research on education needs and the performances of Roma students.

Table 1 Available cross-references in the reviewed texts

\begin{tabular}{rc}
\hline Possible cross-reference rate & Number of studies \\
\hline Over $20 \%$ & 2 \\
$16-20 \%$ & 2 \\
$11-15 \%$ & 16 \\
$6-10 \%$ & 8 \\
$1-5 \%$ & 7 \\
$0 \%$ & 22 \\
\hline
\end{tabular}

To understand the cross-referencing patterns in the field, we examined the data more closely, trying to answer the question of whether the studies published later quoted the colleagues in the field more frequently. The results are displayed in the Figure 2, showing the average frequency of quotations from reviewed studies in the timeline.

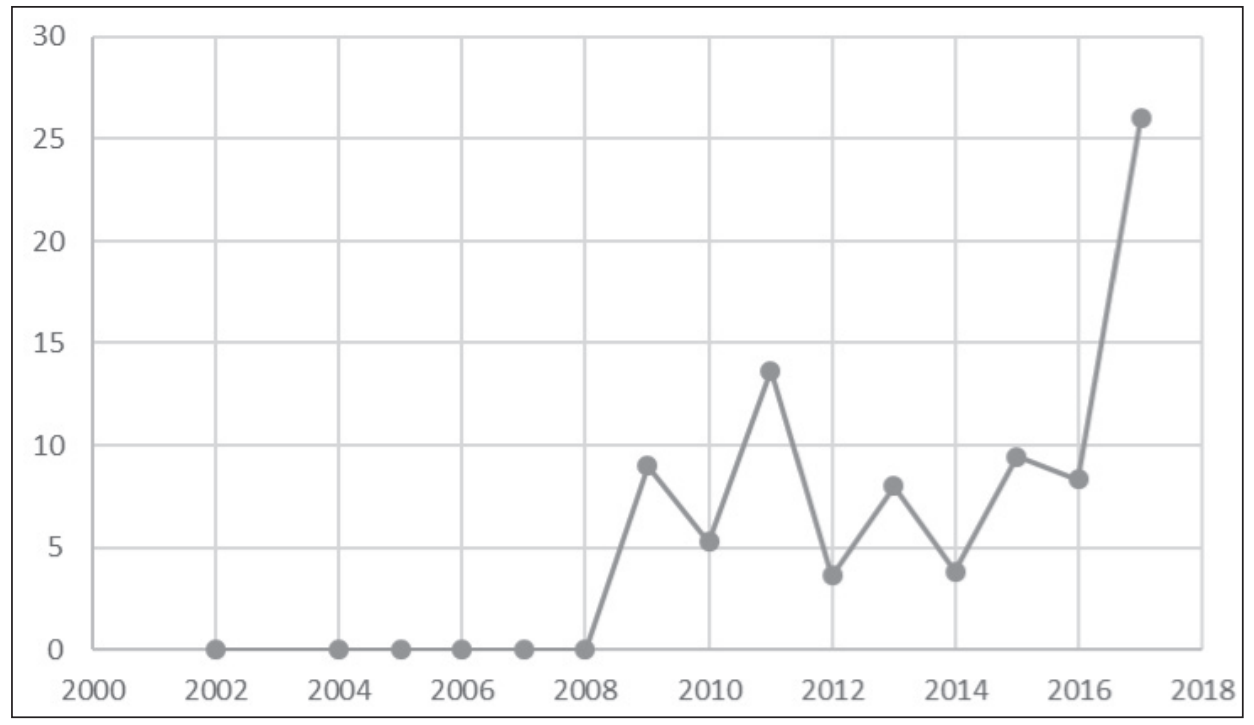

Figure 2 The frequency of quotations from reviewed studies, average by year of publication

The data shows that during the first phase, until 2008, there were no references to the works of other colleagues from the reviewed studies even though there were very few studies available. It could therefore be assumed that the community of 
96 researchers must have been in intense contact, ${ }^{12}$ whereas from 2009 on, referencing other texts in the research field becomes more of a habit. In spite of the fact that the development since 2009 has been uneven, we may expect less terminological fragmentation in the future. After analysing the cross-referencing of analysed texts, we then outlined the most influential studies in the field from the researched period, which may help international readers to understand developments in the Czech domestic context of the research field.

Table 2 Most quoted studies of the literature review sample

\begin{tabular}{llc}
\hline Study & Research Institute & Cross-references \\
\hline GAC (2009) & Gabal Analysis and Consulting & $46 \%(21 / 46)$ \\
GAC (2006) & Gabal Analysis and Consulting & $28 \%(15 / 54)$ \\
GAC (2007) & Gabal Analysis and Consulting & $27 \%(14 / 52)$ \\
Bittnerová et al. (2011) & Charles University & $26 \%(8 / 31)$ \\
GAC (2015) & Gabal Analysis and Consulting & $25 \%(3 / 12)$ \\
Jarkovská et al. (2015) & Masaryk University & $25 \%(3 / 12)$ \\
Kaleja (2011) & University of Ostrava & $19 \%(6 / 31)$ \\
Kašparová, Souralová (2014) & Masaryk University & $17 \%(3 / 18)$ \\
Straková, Tomášek (2013) & Charles University & $17 \%(4 / 23)$ \\
GAC (2010) & Gabal Analysis and Consulting & $16 \%(6 / 38)$ \\
Kaleja (2013) & University of Ostrava & $13 \%(3 / 23)$ \\
Souralová (2008) & Masaryk University & $12 \%(6 / 50)$ \\
Gabal, Čada (2010) & Gabal Analysis and Consulting & $11 \%(4 / 38)$ \\
Svoboda (2010) & Jan Evangelista Purkyně University & $11 \%(4 / 38)$ \\
Nekorjak et al. (2011) & Masaryk University & $10 \%(3 / 31)$ \\
\hline
\end{tabular}

Note: The studies are listed in descending order according to the most frequently quoted in relative numbers. The numeric expression in parentheses shows how many times the study was quoted in reviewed studies, followed by the possible quoting opportunities due to the publishing year.

When we look at how often the reviewed studies quoted other studies from the sample, we find a very different frequency, as well as representation of the research institutes. The only exception are studies delivered by the GAC research institute - all six studies from the analysed selection are present in the overview of most quoted studies. As we already mentioned, the GAC analysis of socially excluded Roma localities in the Czech Republic belongs among the pioneering research works in the examined field. The generally high standard of analysis delivered by GAC combining qualitative and quantitative methods and easy accessibility of the results due to their well-organized online archive, as well as the national scope of the research,

12 The works published before 2008 referred to legal documents, demographic resources, international resources, compilatory works, and resources from related subject fields, such as ethnology, social anthropology, and psychology. 
made the work of GAC one of the most quoted in the field. Nevertheless, other institutions are quoted as well, and we did not find any significant trend in citing works from diverse research institutions. The most frequented research workplaces that published relevant studies on the analysed topic in the observed time period are Masaryk University, Faculty of Education, Department of Social Education (9 studies); Masaryk University, Faculty of Social Studies, Department of Sociology (8 studies); Masaryk University, Faculty of Education, Department of Special and Inclusive Education (7 studies); Charles University, Faculty of Education, Department of Psychology \& Charles University, Faculty of Humanities, Social Sciences Module (4 studies); and the University of Ostrava, Faculty of Education, Department of Special Pedagogy, Centre for Educational Research (4 studies).

The development of the research field on the education of socially disadvantaged/Roma children and families was considerably influenced by several publications that did not meet the selection criteria of our study. Nevertheless, their influence was significant at the time, so we will briefly introduce them as well. One of the iconic publications of the early 2000s is T. Šišková's overview study on ethnic minority and immigrant groups living in the Czech Republic (2001). Her overview of ethnic minorities living in the country became one of the first resources to be highly cited across disciplines. In our selection of 57 original research studies, reference to T. Šišková appeared ten times. Two other texts, which are not original education research studies, were also extensively cited in the resources we analysed. One is a study on the Roma ethnolect of the Czech language by M. Bořkovcová (2006, cited 5 times); the second is a paper on education research in the Roma environment by L. Gulová (2010, cited 5 times).

\subsection{Analysis of methodological approaches}

In this section, we present the analysis of research questions/goals, methods, research settings, and subjects/objects that we depicted in the review studies. Before we elaborate on specific topics of the methodology analysis, we present an overview of the results in the summarizing Table 3.

\subsubsection{Research questions}

The analysis of research questions/goals in the selected studies render several categories of topics most covered, which range from macro to micro phenomena related to the education of socially disadvantaged Roma students and families. It is important to note that in some studies, the research questions follow more topics from the same category (e.g., some studies followed the perspectives of different kinds of actors within one research project) while others deal with topics from different categories (e.g., they focused on support measures as well as on the perspectives of a specific kind of actor at the same time). Therefore, some of the studies are counted within more than one category of research questions. We have listed the numbers of studies encompassed in respective research question categories so the reader may identify respective studies (see Table 3 ). 
98

\begin{tabular}{|c|c|c|c|c|c|c|c|c|}
\hline 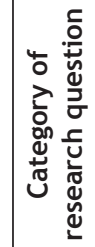 & 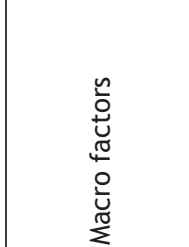 & 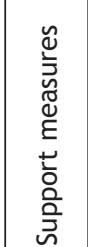 & 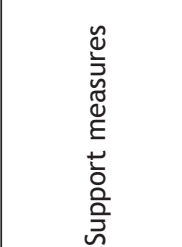 & 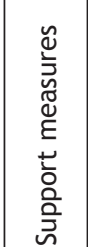 & 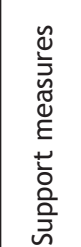 & 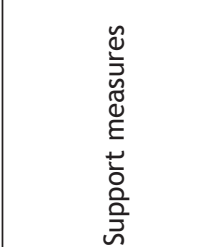 & 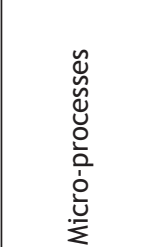 & 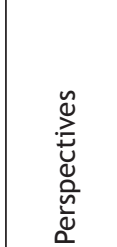 \\
\hline 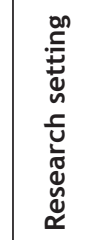 & 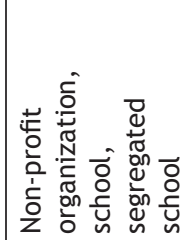 & 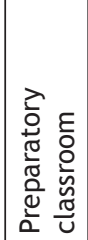 & 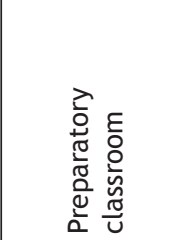 & 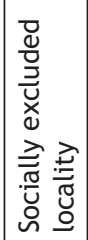 & 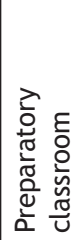 & 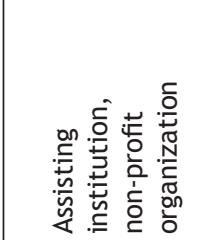 & 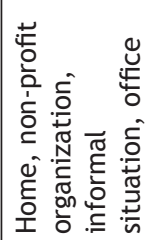 & 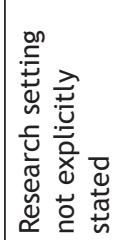 \\
\hline 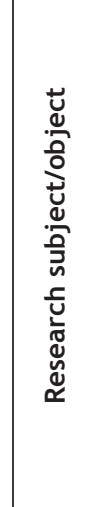 & 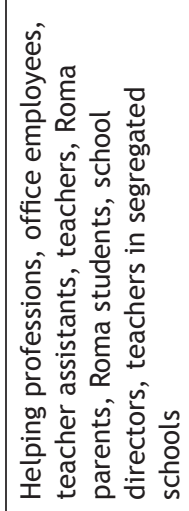 & 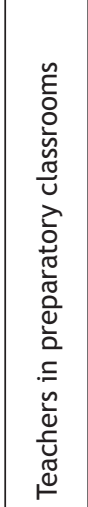 & 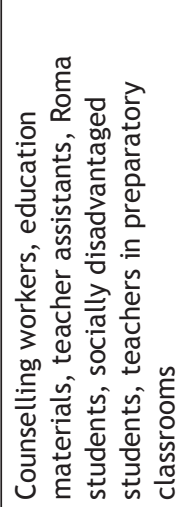 & 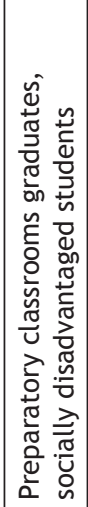 & 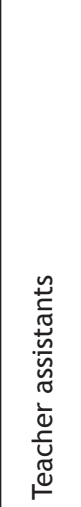 & 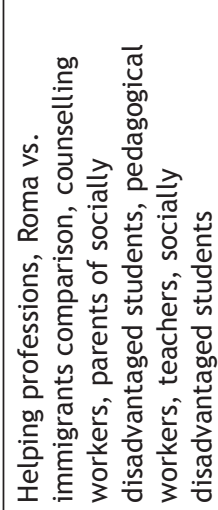 & 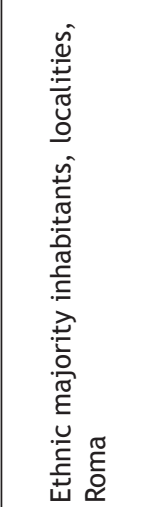 & 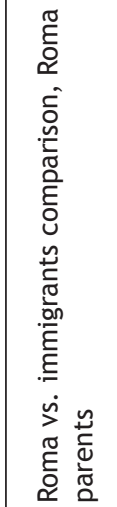 \\
\hline 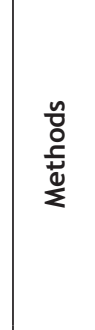 & 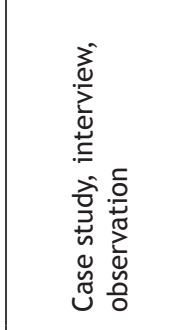 & 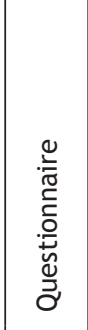 & 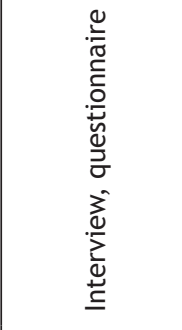 & 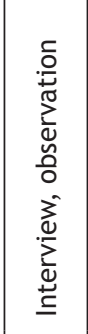 & 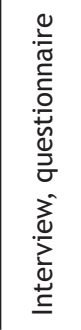 & 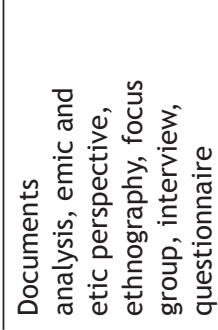 & 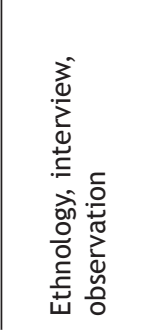 & 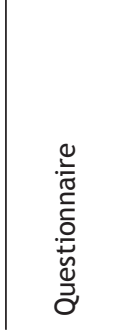 \\
\hline 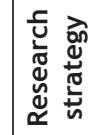 & 承 & 胥 & 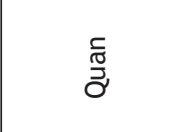 & 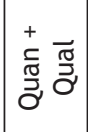 & $\begin{array}{l}\frac{c}{0} \\
\stackrel{\sigma}{\sigma}\end{array}$ & 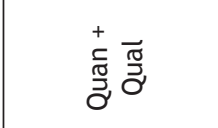 & $\frac{\widetilde{\sigma}}{\widetilde{\sigma}}$ & 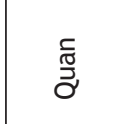 \\
\hline 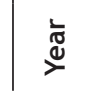 & ఫ্ণ & ర్సి & & 울 & $\stackrel{\text { ¿ }}{\circ}$ & ఫ্ণ & 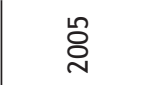 & $\bar{\sim}^{\bar{\nu}}$ \\
\hline 总 & 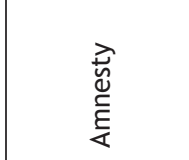 & 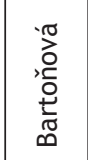 & 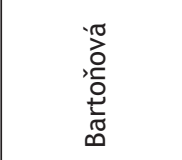 & 告 & 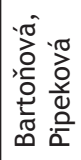 & 离 & 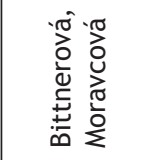 & 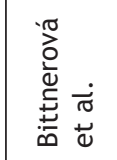 \\
\hline$\dot{d}$ & - & $\sim$ & $m$ & $\nabla$ & n & o & $r$ & $\infty$ \\
\hline
\end{tabular}




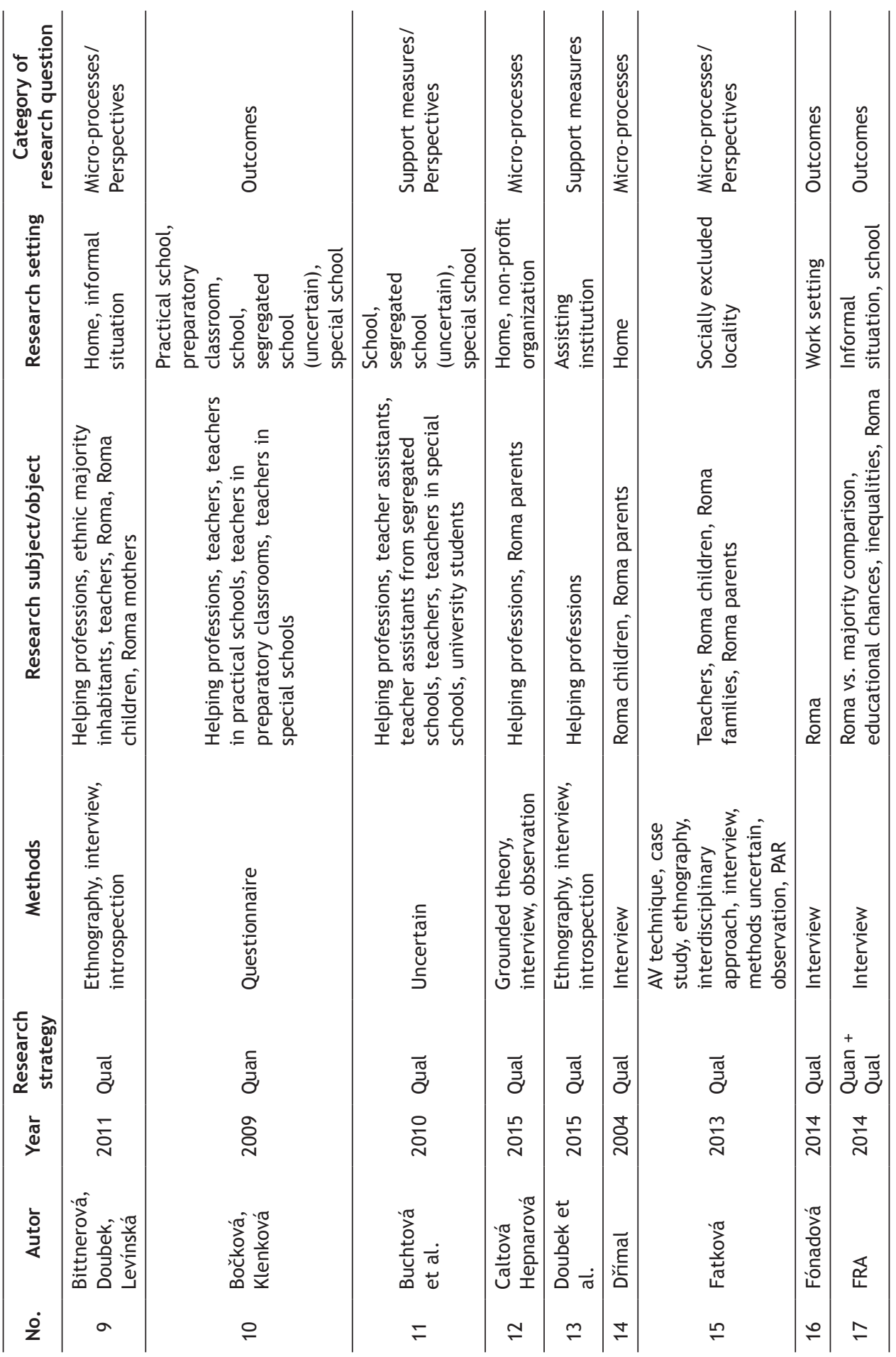


100

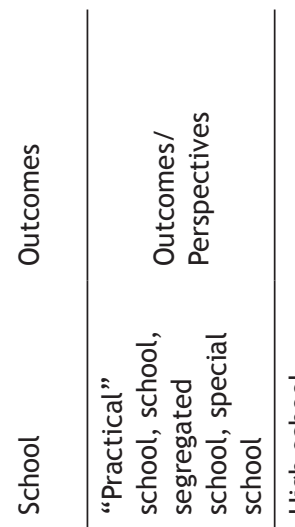

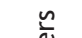

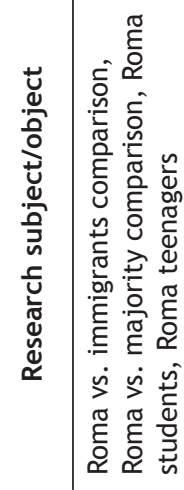

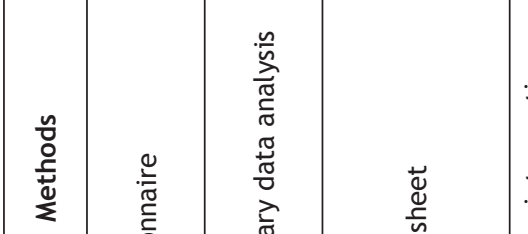

(5)

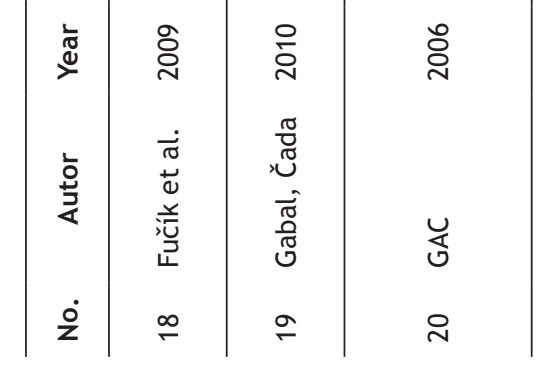




\begin{tabular}{|c|c|c|c|c|c|c|c|c|}
\hline 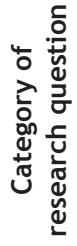 & 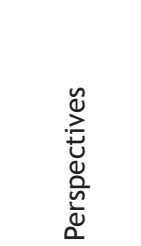 & 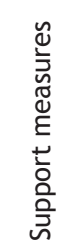 & 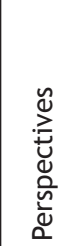 & 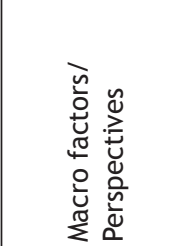 & 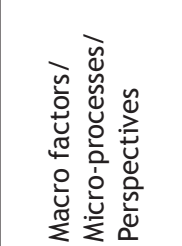 & 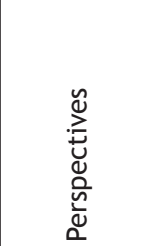 & 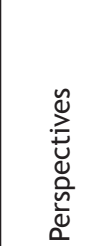 & 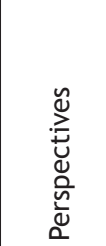 \\
\hline 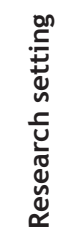 & 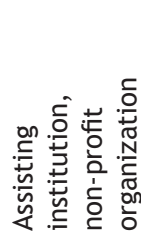 & 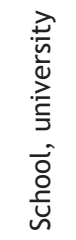 & 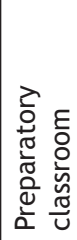 & 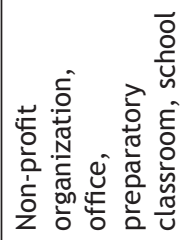 & 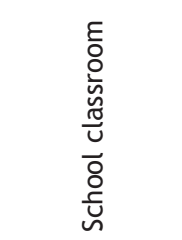 & 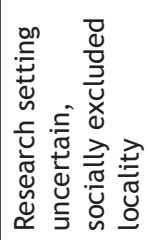 & 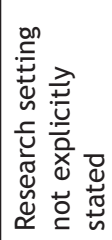 & 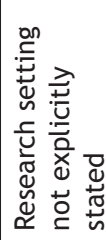 \\
\hline 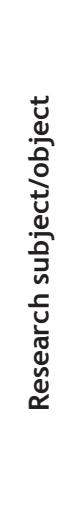 & 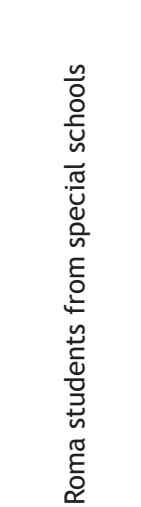 & 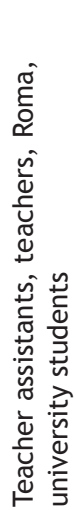 & 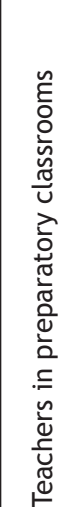 & 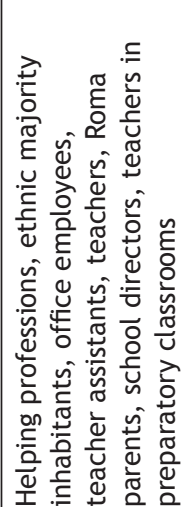 & 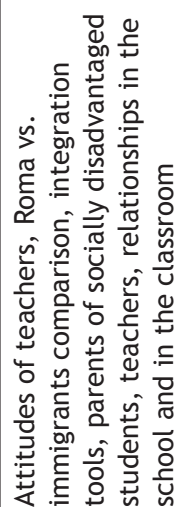 & 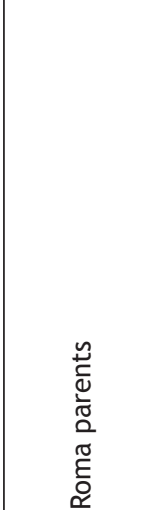 & 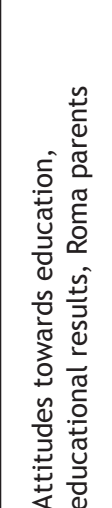 & 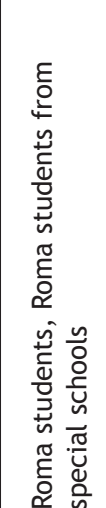 \\
\hline 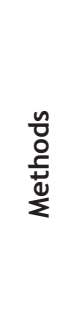 & 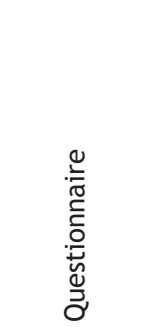 & 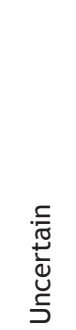 & 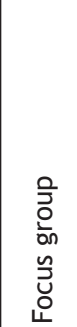 & 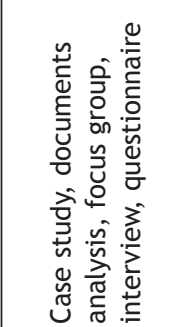 & 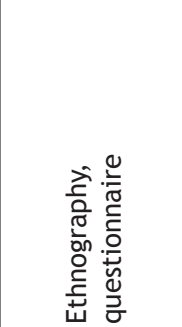 & 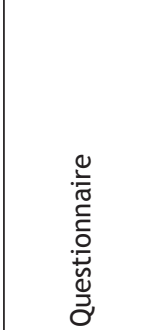 & 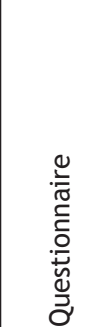 & 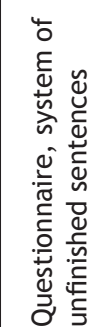 \\
\hline 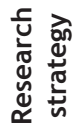 & 离 & $\frac{\widetilde{\sigma}}{\widetilde{\sigma}}$ & $\frac{\pi}{\widetilde{d}}$ & 离 & $\begin{array}{l}\stackrel{+}{\frac{5}{\sigma}} \\
\stackrel{\sigma}{\frac{\sigma}{2}} \frac{\sigma}{\sigma}\end{array}$ & 离 & $\frac{\sqrt{0}}{2}$ & 妾 \\
\hline ֻ & ָㅗำ & ָㅗํ & ठे & $\stackrel{n}{2}$ & $\stackrel{\text { ำ }}{2}$ & 을 & $\bar{i}$ & $\grave{n}_{i}$ \\
\hline 竞 & 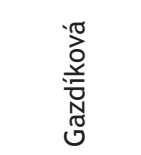 & 登 & 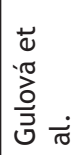 & 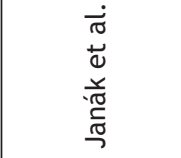 & 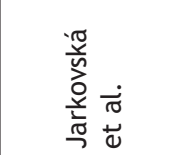 & $\frac{\stackrel{\widetilde{\sigma}}{\mathbb{Q}}}{\underline{\widetilde{\sigma}}}$ & $\frac{\stackrel{\sigma}{Q}}{\frac{\sigma}{\pi}}$ & $\frac{\widetilde{\sigma}}{\frac{\widetilde{\sigma}}{\widetilde{\sigma}}}$ \\
\hline z & $\stackrel{\llcorner}{\sim}$ & N & $\hat{N}$ & $\stackrel{\infty}{\sim}$ & શ & ஓे & $\bar{m}$ & $\underset{m}{m}$ \\
\hline
\end{tabular}


102

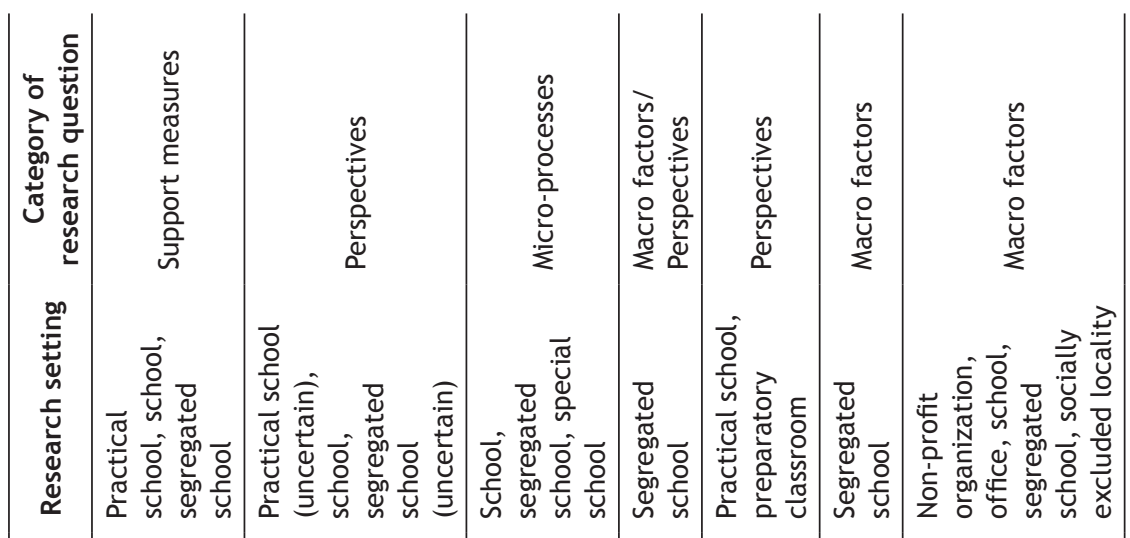

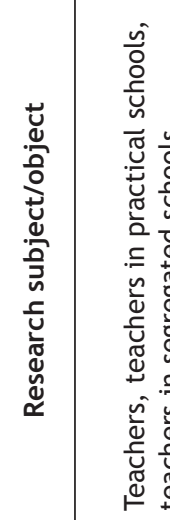

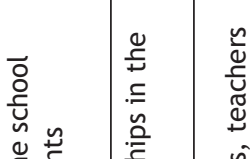

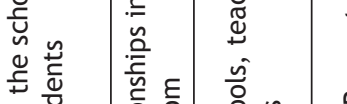

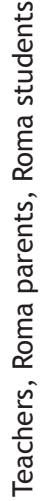

घे जे

วิ 는

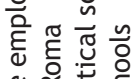

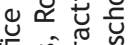

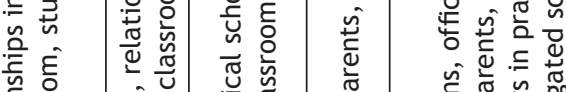

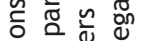

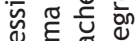

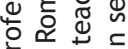

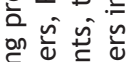

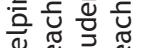

趈

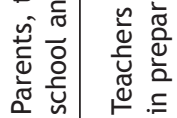

王焉至

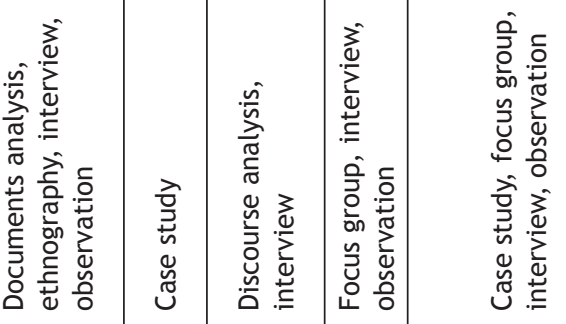

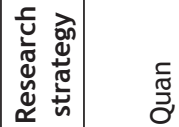

竞

$\begin{array}{lllll}\frac{0}{2} & \frac{0}{2} & \frac{\pi}{2} & \frac{\pi}{2} & \frac{\pi}{2}\end{array}$

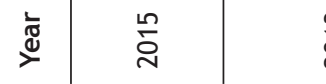

$\frac{\pi}{2}$

$\stackrel{m}{\circ}$

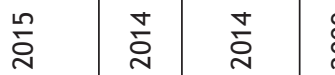

유 휴

$\stackrel{\frac{0}{0}}{\frac{0}{3}}$

$\frac{\pi}{\pi}$

苟

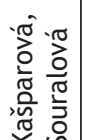

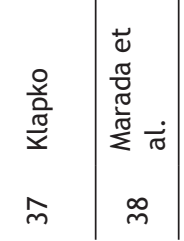

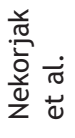

i் m

$\stackrel{n}{m}$

m 


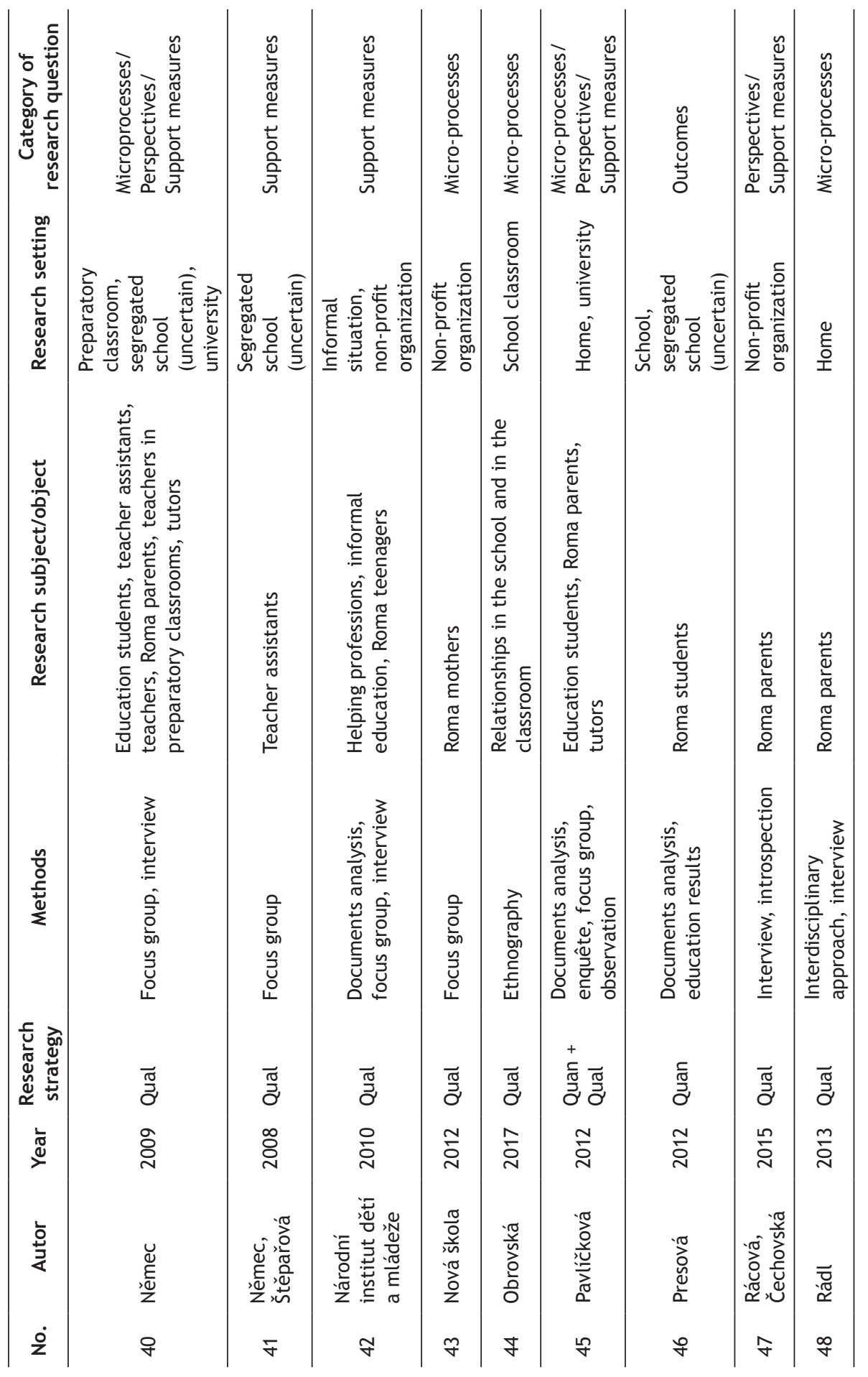


104

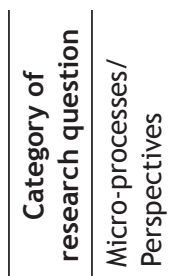

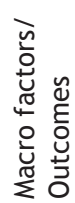

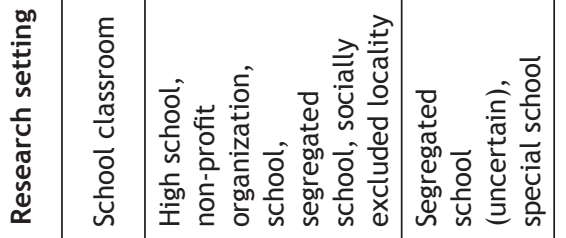

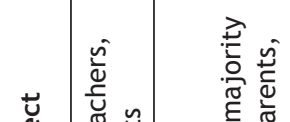

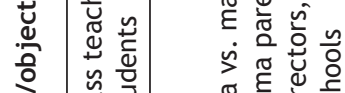

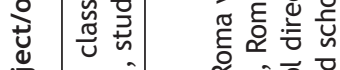

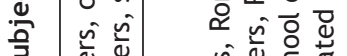

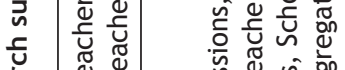

Ũ

岕

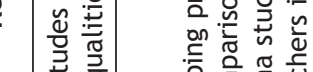

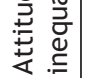

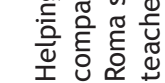

กิ

气ุ

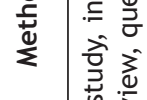

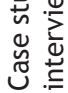

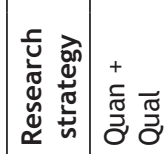

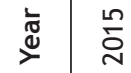

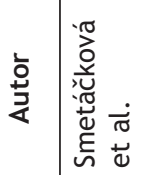

i்

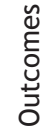

రั

ถั

ᄃ․

市

है

咅

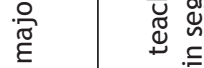

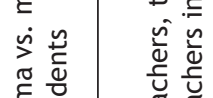

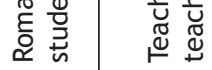

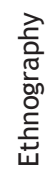

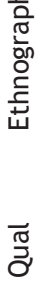

ᄋ్

$\frac{n}{30}$

은

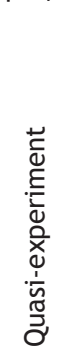

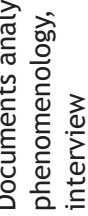

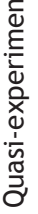

$\frac{\pi}{2}$

రํำ

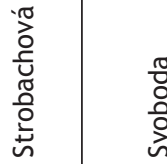

กิ
उ)

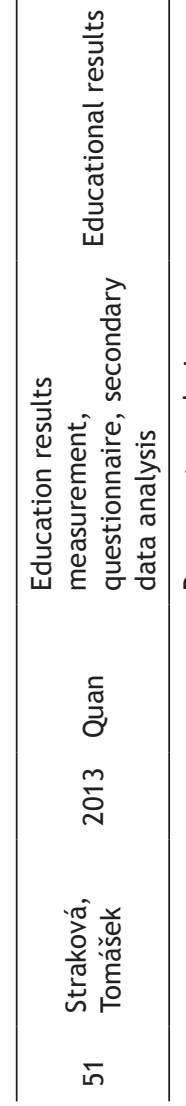

峁

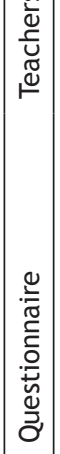

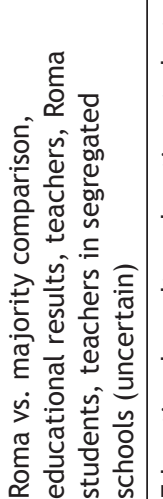

章

号商产

苛 㐫 总

व

ज桴

峁

으 흠

के है

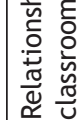

은

气ั้

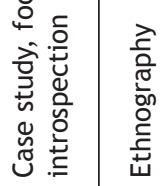

营 $\quad \frac{\pi}{0}$

ㅇํำ

$\frac{\pi}{2} \quad \frac{\pi}{2}$

유 호 유

유 후

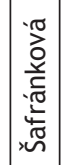

กิ เัก

อั

, in

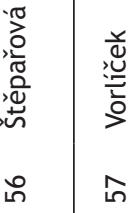


The first category is related to the macro factors underpinning the education of this specific group of subjects, such as educational policy (no. 1, 23, 29), structural conditions (no. 20,24), or causes of school segregation as well as de-segregation (no. $28,36,38,39,50)$. Several studies reflect different factors in educating socially disadvantaged Roma children in their complexity. However, they use rather vague definitions of research questions and thus overlap with other categories we identified.

The second category of research questions/goals discusses the support measures provided for Roma children, students, parents, or families to enhance their success/ results in the educational system. Studies from this category focus on the effects of preparatory classes for socially disadvantaged Roma students (no. 2-4, 56), experiences and problems faced by teaching assistants for socially disadvantaged students (no. 5, 11, 26, 40, 41, 47, 56), the preparedness of teachers for the inclusion of socially disadvantaged Roma students (no. 2), the evaluation of tutoring programs provided by future teachers to socially disadvantaged Roma families (no. 45, 56), or monitoring of (informal) educational activities provided by state and non-governmental organizations in socially excluded localities (no. 6, 13, 19, 56).

The third research questions/goals category includes studies which focus predominantly on the school outcomes of Roma students, comprehended as being either from a static or a dynamic perspective. The first subcategory encompasses studies that analyse the results (usually grades, school attendance) of Roma students on a one-time basis (no. 17, 18, 51) and often focus on reading literacy or language comprehension (no. 10, 55). The second subcategory of studies monitors factors influencing school trajectories and outcomes of Roma children from a complex and longitudinal perspective while taking into account diverse actors as well as factors (no. 16, 19, 21, 22, 23, 46, 50).

The fourth substantial category of research questions/goals reflects the perspectives of different actors involved in educating socially disadvantaged Roma students and families. These are represented by the discourses/opinions of teachers of Roma students, including teachers from preparatory classes (no. 9, 15, 27-29, 36, $37,40,49,53,54)$, perspectives of future teachers or students of social education on the education/tutoring of socially disadvantaged Roma students (no. 11, 40, 45), beliefs of Roma parents related to school and the education of their children (no. $8,9,30,31,40,45,47)$, or meanings Roma children/students themselves construct in relation to school or their future aspirations (no. 9, 18, 25, 32, 34, 52). There is also one study devoted to the opinions of various experts on educating socially disadvantaged Roma students (no. 11).

The last category of studies, as far as their research questions/goals are concerned, focuses on the everyday micro-processes related to education, either in school or in a family context. There is a substantial batch of studies reflecting the micro-social processes constituting childhood in a Roma family/socially excluded locality (no. 9, 12, 15, 14, 40, 43, 45, 48). There is another study explicitly focused on the negotiation of identity by Roma informants (no. 1). Other studies apply an inter- 
106 actional perspective and ethnographic approach to the role of ethnicity in school settings (no. 29, 35, 44, 49, 57).

Even if all of these five categories are saturated approximately evenly, we can observe more significant stress on the macro factors if we posit that the categories 1-3 predominantly represent the broader conditions and factors influencing the education of socially disadvantaged Roma students (policies, curriculum, support measures, school results). The two remaining categories of research questions/goals (the perspectives of actors and everyday micro-processes) cover both the opinions of diverse actors involved in the education of socially disadvantaged Roma children as well as everyday practices which comprise the experience of being a Roma child educated/raised in a Roma family, a socially excluded locality, and/or a segregated or a desegregated classroom. We can conclude that the more micro we look, the fewer studies we find. This pattern is further supported by the following analysis of methods utilized by researchers in the selected studies.

\subsubsection{Methods used in the studies}

The analysis of research methods shows a slight predominance of qualitative design in the research on socially disadvantaged Roma children and families. There are 27 studies in our sample which use solely qualitative research methods, 16 studies use only quantitative methods, while the remaining 12 apply a mixed-method design, combining both qualitative as well as quantitative methods. Numerous studies follow a sophisticated methodological approach, including a thorough epistemological and conceptual base for the conducted research (9 studies apply an ethnographical approach, 8 studies follow a case study design, 1 study was phenomenological, 1 affirms the grounded theory approach, and 1 drew on discourse analysis standpoints); many other studies, however, mentioned only a single method/data collection technique, such as interview or observation.

In the realm of qualitative research, we encounter the prevalence of the interview as the primary research method ( 27 times), followed by the focus group (12 times), and observation (10 times). Document analysis is exploited in nine studies, some of which are quantitative, while others are qualitative.

Within the quantitative/mixed-methods studies, the questionnaire was the primary research instrument (18 times), followed by secondary data analysis ${ }^{13}$ ( 3 times), usage of different kinds of observation sheets (2 times), or tests to verify specific knowledge of Roma students in different areas (reading literacy, a test of unfinished sentences; 2 times).

The dominant position of the interview as a method often applied in research on the education of Roma children and families corresponds to the specific type of research questions which prevails in this field. The analysis shows that almost half the studies in our sample focused on the perspectives of different actors on education

13 Secondary data analysis was applied in several studies as a procedure to analyse previously collected large data sets within other research projects with specific focus on Roma pupils (e.g. as PISA in Straková \& Tomášek, 2013). 
(28 times), for which the interview as a method fits this purpose perfectly. As we suggested above, a stronger emphasis was put on macro factors, support measures, school outcomes, and/or perspectives in this field, and the frequent application of interviews or questionnaires corresponds to this research pattern. On the other hand, the use of methods focused on everyday lives and the first-hand experiences of researched subjects and other micro-processes is marginal despite increasing in recent years (14 times). The effort to capture the complex nature of the education of socially disadvantaged subjects calls for research designs such as ethnography, case study, and participatory or action research. Because these methodologies are more time and cost consuming, it is not surprising that research based on questionnaires or interviews with the most accessible actors (teachers usually) remains dominant.

\subsubsection{Research setting}

Schools and other educational institutions are the prevailing research settings where researchers collect data for their studies. In sum, study data was collected 94 times in schools and school-related settings. Very often, research is conducted in a public primary school (23 times) while further settings include ethnically segregated schools (10 times), preparatory classrooms (8 times), so-called practical schools (6 times), individual schools (6 times), classrooms (4 times), high schools (2 times), or universities (3 times). In some studies, the setting is indeterminate as the authors do not state explicitly whether the school is ethnically segregated or not (8 times) or whether it is a practical school (1 time), although there are some indicators to assume this. In four cases, the research setting is uncertain. Typically, it is research based on distributing questionnaires among Roma parents without specification of the setting where the questioning is taking place. Other school-related settings identified in the studies were non-profit organizations (13 times) and office settings (6 times).

In contrast, the natural settings of Roma informants are underrepresented in our sample. A socially excluded locality as the primary research setting appears in eight studies, while eight other studies took place in a home setting. Informal situations are mentioned four times by authors of several studies as relevant contexts where they collect their data. One study mentioned lodge housing, and one researcher visited the informant at work. In total, research settings other than school-related were chosen 22 times.

The prioritization of education-related institutions in education research is understandable; however, we identified a tendency to focus mainly on pedagogical professionals as the main subjects of the studies (see above) and/or the use of teachers and other pedagogical professionals as gatekeepers securing access to Roma parents/students. This fact can have a significant impact on whether a rapport between researcher and informant is/not established. If a Roma parent considers the researcher as part of the school institution, the validity of the collected data can be jeopardized. A parent may choose to answer a questionnaire in a socially desirable 
108 way because they perceive the researcher as exerting control over their child, and therefore, the issue of the validity of conducted studies emerges.

\subsubsection{Subject/object of the research}

The patterns, which concern, as mentioned earlier, the most common research methods in the field studying the education of socially disadvantaged Roma children and families, bring us to the dominant subjects/objects of the analysed texts. The position may be shown in the research design, including procedures for generating research questions, but also for elaborating on the results. Therefore, on the one hand, there are highly structured research tools that include only short term and structured contact with people in the research field versus anthropologic and participative co-creative research tools that explore participants' perspective within a broader context and take into account their suggestions for problem solving and interpretative frames (Fay, 1996; Guba \& Lincoln, 1994). As such, methodologies may symbolically reproduce interpersonal relationships in the social field, and therefore the objectifying research tools can be criticized for being in danger of symbolically reproducing social inequalities (Fine, 1994).

The most frequent subject of research are teachers in public primary schools (23 times), ${ }^{14}$ in ethnically segregated schools (6 times), in so-called practical schools (5 times), in preparatory classrooms for socially disadvantaged children (6 times), or in individual schools ( 2 times). Furthermore, a substantial number of studies focus on other non/pedagogical professionals working with socially disadvantaged Roma children and students, such as school directors (5 times), teacher assistants ( 11 times), student teachers (5 times), tutors ( 3 times), and other helping professions (e.g., social workers from non-profit organizations and counselling workers; 15 times). Five studies reflect the views of office employees representing institutions in charge of formulating educational policies or grant schemes supporting this common area. In total, pedagogical or non-pedagogical professionals directly or indirectly working with socially disadvantaged Roma children or families are at least one of the targeted subjects/objects 86 times.

On the other hand, Roma subjects/objects are the focus of studies from our sample much less often - Roma parents (17 times), Roma in general (8 times), 15 Roma students (15 times), Roma children under the age of six years (4 times), Roma teenagers ( 3 times), Roma students in individual schools ( 2 times), and preparatory classrooms graduates (1 time). In total, different kinds of Roma actors are the target of the selected studies 50 times.

Some studies compare educational results/perspectives or voices of Roma students with those of majority students (6 times), while others contrast Roma with

14 Some of the public primary schools may be ethnically segregated. However, this could not be identified clearly in numerous analysed studies.

15 We used the code "Roma" to specify the subject/object of the study in cases where it was not possible to identify which subcategories this category encompassed (e.g., Roma parents or children or families or both). 
migrants (4 times). Sometimes, ethnic majority inhabitants are mentioned as being part of the study ( 3 times), students without the adjective Roma are mentioned in two studies ( 2 times), parents of socially disadvantaged children are also included (2 times), and one study included only parents without further specification (1 time). In these cases, we were not sure whether they should be included in already existing coding categories or whether they indicate a mixture of Roma as well as majority socially disadvantaged subjects being part of the studies. This brings us back to the difficulties of many authors in defining who is/not a Roma for their research, and as a result of which, some of them worked with the more general term socially disadvantaged student/parent, and so on. (see section 1.2 Terminology).

We may conclude that in the research of socially disadvantaged Roma children and families, the attitudes, perspectives, experiences, or strategies of actors representing the ethnic-majority society are present much more often than the perspectives of Roma subjects. This implies a danger of reproducing biases and ethnocentric assumptions; ethnic-majority actors avoid this only with difficulty. Majority researchers are also in danger of unintentional reproduction of ethnocentric viewpoints or outcome-driven discourses. Even though they strive to critically reflect on them and/or distance themselves from them, most of the researchers have a habitus that is too far remote from the life experiences of their Roma informants/respondents. This is in accordance with the finding that the gender dimension, often researched using the intersubjective approach, is reflected in the research design of reviewed studies rather rarely. ${ }^{16}$

\section{Discussion and conclusion}

The main incentive to develop this literature review was to make Czech education research on socially disadvantaged/Roma children available to the international community. During work on the ISOTIS research project, we learned that it is challenging to share general research results but also proceedings within the Czech context. Some international projects on education tend to compare the education of immigrants from western European countries with the education of Roma in southeastern European countries (ISOTIS, 2019; Marada et al., 2009). National research projects often have more independent agendas that more accurately reflect the demographic and cultural situation in the respective country. Therefore, it is important to share as many resources as possible, not only within the international research projects consortia.

Silence had prevailed in Czech education science until 2007, and the topic of the educational needs of Roma children was non-existent before then. To a certain extent, it reflected the silence in the general public discourse, but it also partly seemed to be due to a lack of up-to-date research methodology. It is essential to

16 Only one study includes gender in research questions formulation (Smetáčková et al., 2015), and two in research findings (Jarkovská et al., 2015; Souralová, 2008). 
110 stress that a more intense publication activity in this area started only 12 years ago, a short period of time in scientific research. As we had expected, most of the critical research in the field is produced by a few research institutions. At least they are spread across the country, and therefore a systematic research endeavour has been conducted in Prague, Brno, and Ostrava. Moreover, the role of nationwide research carried out by the research institute GAC has been irreplaceable in the past decade. It seems that over the course of time, the researchers have started to refer to each other's work, and therefore, we can expect a more significant synergic effect in their work in the future. Despite that, we see a structural barrier in that there is no database/repository of published texts in this field written in the Czech language, which would help catalyze interdisciplinary debates and support cross-referencing habits among diverse institutions. Especially in the case of the studies published in reviewed journals not indexed in SCOPUS or WOS databases, it is challenging to reach them systematically through Czech library catalogues and databases - and that is not to speak of the research reports and other publication outcomes not highly evaluated by the standard academic metric system.

The analysis of research questions in 57 selected studies generated five categories. These are macro factors, support measures, education outcomes, perspectives, and micro-processes. Despite the relatively even distribution, it can be said that the lowest attention is paid to micro-processes. The pervading preference of using questionnaires and interviews with pedagogical professionals as research tools not only reflects how research methodology is taught and practiced in education research institutions but also limits the possibilities of culturally sensitive analysis of the issue. The usage of the Romany language as a supportive research tool is practically absent in Czech education research since Roma researchers/academics are represented in the field only marginally (for an exception, see studies written, e.g., by M. Kaleja, M. Rácová, \& E. Štěpařová); ${ }^{17}$ therefore, we may assume some meaning layers remain hitherto uncovered.

The education research concerning the education of socially disadvantaged/Roma children and families takes place predominantly in formal, school settings. This, in combination with the preferred methods of research, supports the objectification of Roma students and families as rather passive, non-competent, "unsuccessful" products of specialized efforts of specialized professionals. Reproducing the hierarchical scheme of teacher/expert and student/product does not help support Roma families in taking over responsibility for their education or using family resources to achieve a better education.

The abovementioned systematic review of Lauritzen and Nodeland concludes that "Roma is primarily perceived as either the problem or the victim and rarely as a resource" (2018, p. 164). To support the development of research on the education of socially disadvantaged Roma children and families, we recommend the utilization

17 Some research projects put emphasis on data collection solely by Roma interviewers (see Slovo $21,2014)$; however, this is to our knowledge, and based on the analysed studies, rather exceptional. 
of more participatory methodologies as these are sensitive to emic perspectives of research participants and thus enable better management of the undesired subject-object power effects; concentration on the everyday experiences of the most marginalized subjects in this field - Roma children, students and teenagers; and last but not at least the involvement of Roma researchers/interviewers in the research designs. A reservoir of texts published in this field concentrated in some repository/ database would help to enhance cross-referencing in academic papers. However, it also develops support measures targeted at socially disadvantaged Roma children and families based on more robust scientific proofs.

Hopefully, after another decade of education research and social development in the Czech education system, more good news and promising practices will be presented, and the worrying trend of an education gap between the ethnic majority Czechs and the Czech Roma population will be stopped or even reversed. We seem to be still far from finding the proper tools to tackle ethnic-based inequalities in the Czech educational system, and based on the literature review study results, we can only support investing more efforts in the field to see more curricular results in the future.

\section{Acknowledgments}

This paper was written based on the resolution of the ISOTIS project (www.isotis .org) and funded by the European Union within the Horizon 2020 Framework Programme (Grant agreement No. 727069). We want to express our gratitude to Masaryk University librarian Mr. Jan Hanuš for his assistance in searching the catalogues and databases for the resources we included in this literature review.

\section{References}

In this list of references, the publications included in our research sample of analysed studies are marked with an asterisk.

*Amnesty International. (2009). Nedokončený úkol: Romští žáci v České republice stále čelí překážkám ve vzdělání. London: Amnesty International.

Barša, P. (2008). Konstruktivismus a politika identity: Odpověd' Tomáši Hirtovi a Markovi Jakoubkovi. In M. Jakoubek \& L. Budilová (Eds.), Romové a cikáni - neznámí i známí: Interdisciplinární pohled (pp. 208-243). Voznice: Leda.

*Bartoňová, M. (2002). Prípravné třídy jako jedna z forem pedagogické intervence u dětí z jiného sociokulturního etnika [Doctoral dissertation, Masaryk University, Faculty of Education, Brno, Czech Republic]. Retrieved from https://is.muni.cz/auth/th/tbnas/text.pdf

*Bartoňová, M. (2008). Vzdělávání dětí se sociálním znevýhodněním v prípravné třídě základní školy v období 2002-2008. In M. Bartoňová, M. Vítková et al. (Eds.), Vzdělávání žáků se speciálními vzdělávacími potřebami II (pp. 77-96). Brno: Paido.

*Bartoňová, M. (2010). Žáci se sociálním znevýhodněním v rámci inkluzivního vzdělávání s akcentem na osvojení si klíčových kompetencí. In J. Havel, H. Filová et al. (Eds.), Inkluzivní vzdělávání v primární škole (pp. 91-102). Brno: Paido. 
112 *Bartoňová, M., \& Pipeková, J. (2008). Asistent pedagoga v přípravné třídě základní školy. In M. Bartoňová, M. Vítková et al. (Eds.), Vzdělávání žáků se speciálními vzdělávacími potřebami II (pp. 229-244). Brno: Paido.

*Bittnerová, D. (2009). Vzdělávací potřeby sociokulturně znevýhodněných: Případ SIM - Středisek integrace menšin. Prague: Ermat. Retrieved from http://toc.nkp.cz/NKC/201002 /contents/nkc20092023085_1.pdf

*Bittnerová, D., Doubek, D., \& Levínská, M. (2014). Funkce kulturních modelů ve vzdělávání. Prague: FHS UK.

*Bittnerová, D., \& Moravcová, M. (2005). Kdo jsem a kam patřím?: Identita národnostních menšin a etnických komunit na území České republiky. Prague: Sofis.

Bittnerová, D., Moravcová, M., \& Pěničková, D. (2011). Cíle romských rodičů při výchově a vzdělávání vlastních dětí. In D. Bittnerová \& M. Moravcová (Eds.), Etnické komunity: Integrace, identita (pp. 113-152). Prague: FHS UK.

*Bočková, B., \& J. Klenková (2009). Komunikační schopnosti žáků se sociálním znevýhodněním. In J. Němec \& V. Vojtová (Eds.), Vzdělávání žáků se sociálním znevýhodněním (pp. 91-102). Brno: Paido.

Bořkovcová, M. (2006). Romský etnolekt češtiny: Případová studie. Prague: Signeta.

Brüggermann, C., \& Friedman, E. (2017). The decade of Roma inclusion: Origins, actors, and legacies. European Education, 49(1), 1-9.

*Buchtová, Z., Gulová, L., \& Štěpařová, E. (2010). Problematika vzdělávání romských žáků v kontextu výzkumných šetření (vymezení témat výzkumných šetření). In L. Gulová et al., Analýza vzdělávacích potřeb romských žáků (pp. 8-55). Brno: Muni PRESS.

*Caltová Hepnarová, Gabriela (2015). Systémový pohled na problémovou romskou rodinu a její výchovné působení [Doctoral dissertation, Palacký University Olomouc, Faculty of Education, Olomouc, Czech Republic]. Retrieved from https://theses.cz/id/wre91g / Disertan-prce-Gabriela-Caltov-Hepnarov-final.pdf

Council of Europe. Court of Human Rights. Grand Chamber. (2007). Case of D.H. and Others v. the Czech Republic. (Application no. 57325/00) (Judgment). Retrieved from https: / /www .escr-net.org/caselaw/2017/case-dh-and-others-v-czech-republic-app-no-5732500-grandchamber-final-judgment-13

Cviklová, L. (2015). Direct and indirect racial discrimination of Roma people in Bulgaria, the Czech Republic, and the Russian Federation. Ethnic and Racial Studies, 38(12), 2140-2155.

Čechovská, L. (2014). Etnická identita Romů v akademických konfrontacích. Pole etnicity jako nejasný prostor pro vstup do debaty o etnické identitě Romů. Slovenský Národopis, 62(1), 106-118.

Červenka, J. (2009). Sociolingvistický výzkum situace romštiny na území ČR: Výzkumná zpráva. Prague: Seminář romistiky, ÚJCA FF UK.

*Doubek, D., Levínská, M., \& Bittnerová, D. (2015). Pomoc a pořádek: Kulturní modely $\checkmark$ pomáhajících profesích. Prague: FHS UK.

*Dřímal, F. (2004). Dětství v romské rodině. In I. Nosál (Ed.), Obrazy dětství v dnešní české společnosti: Studie ze sociologie dětství (pp. 65-90). Brno: Barrister \& Principal.

*Fatková, G. (2013). Limity antropologie dětství: Případ “dětství” v sociálně vyloučené lokalitě. Lidé Města: Urban People, 15(1), 27-47.

Fay, B. (1996). Contemporary philosophy of social science: A multicultural approach. Oxford: Blackwell.

Fine, M. (1994). Working the hyphens. Reinventing self and other in qualitative research. In N. K. Denzin, \& Y. S. Lincoln (Eds.), Handbook of qualitative research (pp. 70-82). Thousand Oaks: SAGE.

*Fónadová, L. (2014). Nenechali se vyloučit: Sociální vzestupy Romů v české společnosti (kvalitativní studie). Brno: Masarykova univerzita.

Fónadová, L., Katrňák, T., \& Simonová, N. (2019). The Czech Republic: From ethnic discrimination to social inclusion in the educational system. In P. A. J. Stevens \& A. Gary Dworkin (Eds.), The Palgrave handbook of race and ethnic inequalities in education. Volume 1. (pp. 381-421). Cham (Switzerland): Palgrave Macmillan. 
FRA (European Union Agency for Fundamental Rights). (2012). The situation of Roma in 11 EU member states: Survey results at glance. Luxembourg: Publication Office of the European Union.

*FRA (European Union Agency for Fundamental Rights). (2014). Vzdělávání: Situace Romů $\checkmark$ jedenácti členských státech EU: Průzkum romské populace - zaměřeno na údaje. Luxembourg: Úřad pro publikace Evropské unie. Retrieved from fra.europa.eu/sites/default /files/fra./fra-2014-roma-survey-dif-education_cs.pdf

FRA (European Union Agency for Fundamental Rights). (2016). Second European minorities and discrimination survey: Roma - selected findings. Luxembourg: Publication Office of the European Union.

*Fučík, P., Haltufová, M., Marada, R., \& Nekorjak, M. (2009). Ethnic differences in education in the Czech Republic: Survey report. Budapest: Center for Policy Studies CEU. EduMigRom: Survey Studies. Retrieved from https://www.edumigrom.eu/sites/default/files / field_attachment/page/node-5387/edumigromsurveyreportczech-republic.pdf

*Gabal, I., \& Čada, K. (2010). Romské děti v českém vzdělávacím systému. In P. Matějů, J. Straková, \& A. Veselý (Eds.), Nerovnosti ve vzdělávání: Od měření k řešení (pp. 109-129). Prague: Sociologické Nakladatelství (SLON).

*GAC (2006). Analýza sociálně vyloučených romských lokalit a absorpční kapacity subjektů pưsobících $v$ této oblasti. Prague: GAC Spol.

*GAC (2007). Analýza postojů a vzdělávacích potřeb romských dětí a mládeže. Prague: GAC Spol.

*GAC (2009). Vzdělanostní dráhy a vzdělanostní šance romských žákyň a žákủ základních škol $\checkmark$ okolí vyloučených romských lokalit: Závěrečná zpráva projektu MŠMT ČR Sociologický výzkum zaměřený na analýzu podoby a příčin segregace dětí, žákyň, žáků a mladých lidí ze sociokulturně znevýhodňujícího prostředí. Prague: GAC Spol.

*GAC (2010). Sociologická analýza přechodů romských dětí ze sociálně vyloučeného prostredi ze základních na střední školy. Prague: GAC Spol.

*GAC (2015). Analýza sociálně vyloučených lokalit $v$ ČR. Prague: GAC Spol.

*Gazdíková, O. (2012). Romové a vzdělávání [Rigorous work, Charles University, Faculty of Arts, Prague, Czech Republic]. Retrieved from https://is.cuni.cz/webapps/zzp/detail/114295

Guba, E. G., \& Lincoln, S. (1994). Competing paradigms in qualitative research. In N. K. Denzin \& Yvonna S. Lincoln (Eds.), Handbook of qualitative research (pp. 105-117). Thousand Oaks: Sage.

Gulová, L. (2010). Několik tezí k analýze výzkumných šetření. In L. Gulová et al., Analýza vzdělávacích potřeb romských žáků (pp. 207-209). Brno: Masarykova Univerzita.

*Gulová, L. (2012). Reflexe k tématům vzdělávání v kontextu romské populace. In M. Kaleja (Ed.), Romové - otázky a odpovědi v českém a slovenském kontextu (pp. 138-155). Ostrava: Ostravská univerzita v Ostravě, Pedagogická Fakulta.

*Gulová, L., Němec, J., \& Štěpařová, E. (2007). Edukace sociálně zvenýhodněných žáků Romský žák $v$ prrípravné třídě z pohledu učitelů. In M. Vítková et al., Vzdělávání žáků se speciálními vzdělávacími potřebami I (pp. 127-142). Brno: Paido.

Hurrle J., Sýkora L., Trlifajová L., \& Kučera, P. (2016). Socially excluded localities revisited. Geografie, 121(4), 544-565.

Igarashi, K. (2005). Support programmes for Roma children: Do they help or promote exclusion? Intercultural Education, 16(5), 443-452.

ISOTIS (2019). ISOTIS publications. Retrieved from http://www.isotis.org/resources /publications/isotis-publications

*Janák, D., Stanoev, M., Tvrdá, K., Walach, V., Pilát, M., \& Hlavienka, L. (2015). Rozšiřit rečiště hlavního vzdělávacího proudu: Sociální inkluze žáků a transformace vzdělávacího systému v Krnově a v Sokolově. Opava: Slezská univerzita v Opavě, Fakulta veřejných politik.

Jarkovská, L., Lišková, K., \& Obrovská, J. (2015). “We treat them all the same, but ...”. Disappearing ethnic homogeneity in Czech classrooms and teachers' responses. Race, Ethnicity and Education, 18(5), 632-654. 
114 *Jarkovská, L., Lišková, K., Obrovská, J., \& Souralová, A. (2015). Etnická rozmanitost ve škole: Stejnost v různosti. Prague: Portál.

*Kaleja, M. (2010). Analýza postojů rodičů romských dětí ke vzděláván [Dissertation thesis, Masaryk University, Faculty of Education, Brno, Czech Republic]. Retrieved from https:// is.muni.cz/th/sf469/DISERTACE_pdf.pdf

*Kaleja, M. (2011). Romové a škola versus rodiče a žáci. Ostrava: Ostravská univerzita v Ostravě, Pedagogická fakulta.

*Kaleja, M. (2013). Vzdělávání jako hodnota u romských žáků. In M. Kaleja (Ed.), Determinanty hodnotových konstruktů ve vzdělávání romských žáků základních škol (56-95). Ostrava: Ostravská univerzita v Ostravě, Pedagogická fakulta.

*Kaleja, M. (2015). (Ne)připravený pedagog a žák z prostředí sociální exkluze. Opava: Slezská univerzita $\vee$ Opavě, Fakulta veřejných politik.

*Kaleja, M., \& Krpec, R. (2013). Kvantitativní analýza názorů a postojů romských žáků ke vzdělávání. Grant Journal, 2(1), 18-23.

*Kaleja, M., Zezulková, E., Adamus, P., \& Mühlpachr, P. (2015). Etnografie školy jako edukačni realita současnosti. Opava: Slezská univerzita v Opavě, Fakulta veřejných politik.

*Kašparová, I., \& Souralová, A. (2014). “Od lokální k cikánské škole”: Homogenizace školní třídy a měnící se role učitele. Orbis Scholae, 8(1), 76-96.

*Klapko, D. (2014). Diskursivní analýza názorů pedagožek ZŠ na vzdělávání romských žáků. In D. Klapko, \& L. Remsová et al., Výzkumný exkurz do diskursů o Romech (pp. 87-130). Brno: Masarykova univerzita.

Lauritzen, S. M., \& Nodeland, T. S. (2018). "What is the problem represented to be?" Two decades of research on Roma and education in Europe. Educational Research Review, 24, 148-169.

Levínská, M. (2013). Možnosti zvládání interkulturní komunikace. Případ českých Romů na české škole. In D. Bittnerová \& M. Moravcová (Eds.), Etnické komunity: Romové (pp. 113-132). Prague: FHS UK.

*Marada, R., Nekorjak, M., Souralová, A., \& Sidiropulu Janků, K. (2009). Case study on ethnic minorities: Czech Republic. Brno: Masarykova univerzita.

Mareš, J. (2013). Přehledové studie: Jejich typologie, funkce a způsob vytváření. Pedagogická Orientace, 23(4), 427-454.

Mayall, D. (2004). Gypsy identities 1500-2000: from Egyptians and Moon-men to the ethnic romany. London: Routledge.

Ministerstvo školství, mládeže a tělovýchovy ČR (2015). Konsolidovaný text školského zákona a doprovodný materiál dle novely č. 82/2015 SB. Retrieved from http://www.msmt.cz /dokumenty-3/konsolidovany-text-skolskeho-zakona-a-doprovodny-material

Ministerstvo školství, mládeže a tělovýchovy ČR (2017). Rámcový vzdělávací program pro základní vzdělávání. Praha: MŠMT. Retreived from http://www.msmt.cz/file/41216

Nečas, C. (1999). Romové v České republice včera a dnes. Olomouc: Univerzita Palackého.

Nedbálková, K., \& Sidiropulu Janků, K. (2015). Doing research, making science: The memory of Roma workers. Brno: Centre for the Study of Democracy and Culture.

*Nekorjak, M., Souralová, A., \& Vomastková, K. (2011). Uvíznutí v marginalitě: Vzdělávací trh, "romské školy" a reprodukce sociálně prostorových nerovností. Sociologický časopis, 47(4), 657-680.

*Němec, J. (2009). Sociální a kulturní determinanty a strategie edukace romských žáků. Orbis Scholae, 3(1), 99-120.

*Němec, J., \& Štěpařová, E. (2008). Edukace sociálně znevýhodněných žáků z pohledu asistentů pedagoga brněnských základních škol. In M. Bartoňová, M. Vítková et al., Vzdělávání žáků se speciálními vzdělávacími potřebami II (pp. 245-264). Brno: Paido.

Němec, Z., Simáčková-Laurenčíková, K., Hájková, V., \& Strnadová, I. (2015). “When I need to do something else with the other children, then I can rely on her": Teaching assistants working with socially disadvantaged students. European Journal of Special Needs Education, 30(4), 459-473. 
*Národní institut dětí a mládeže (2010). Na křižovatce kultur: Aneb, Romové, Vietnamci a Číñané mezi námi. Prague: Národní institut dětí a mládeže.

*Nová škola (2012). Infant Matter: Raná péče a předškolní výchova a vyhodnocení focus groups. Prague: Nová škola. Retrieved from http://www.novaskolaops.cz/infant-matter-analyza -focus-groups

*Obrovská, J. (2017). Rituály s těmi druhými: Etnografie etnicit a etnizací v desegregované školní třídě [Doctoral dissertation, Masaryk University, Faculty of Social Studies, Brno, Czech Republic]. Retrieved from http://is.muni.cz/th/143665/fss_d

Obrovská, J. (2018). Roma identity and ritual in the classroom: The institutional embeddedness of ethnicity. Cham: Palgrave.

Pastori, G., Pagani, V., \& Sarcinelli, A. S. (2019). Multilingualism and global competence in ECEC \& primary school settings. Report on the ISOTIS Virtual Learning Environment development and implementation in four countries to innovate inclusive and effective curricula and pedagogies. ISOTIS Research report.

*Pavličková, R. (2012). Rodinné podmínky facilitující vzdělávání romských dětí prostrednictvím analýzy projektu "Domácí učitel" [Doctoral dissertation, Masaryk University, Faculty of Education, Brno, Czech Republic]. Retrieved from https://is.muni.cz/th/ehrdy /disertace_finalni_verze.pdf

*Presová, J. (2012). Specifika vzdělávací dráhy žáků se sociálním znevýhodněním [Rigorous work, Masaryk University, Faculty of Education, Brno, Czech Republic]. Retrieved from http://is.muni.cz/th/174515/pedf_r

*Rácová, M. \& Čechovská, L. (2015). Rodiče romských žáků a žákyň ve spektru sociální pedagogiky a inkluzivního vzdělávání. In L. Gulová (Ed.), Aplikace mechanismů sociální pedagogiky do sociální a pedagogické práce: Praxe a výzkum (pp. 25-52). Brno: Masarykova univerzita.

*Rádl, M. (2013). Vnímání věkových stupňů u Romů a jeho vliv na dosahované vzdělání. In D. Bittnerová \& M. Moravcová (Eds.), Etnické komunity. Romové (pp. 133-151). Prague: FHS UK.

Rostas, I., \& Kostka, J. (2014). Structural dimensions of Roma school desegregation policies in central and Eastern Europe. European Educational Research Journal, 13(3), 268-281.

Schmidt, V. (2018). Public health as an agent of internal colonialism in interwar Czechoslovakia: shaping the discourse about the nation's children. Patterns of Prejudice, 52(4), 355-387.

Skupnik, J. (2009). Antropologie, romistika i folkloristika: Jak se hloupý Honza učil kinšipsky. Český lid, 96(1), 87-90.

Slovo 21 (2014). Výzkum o postavení romských žen v České republice. Prague: Slovo 21.

*Smetáčková, I., Jahodová, D., \& Franke, H. (2015). Ambivalence rozšiřování obzorů: Percepce genderu a etnicity na 1. stupni ZŠ: Výzkumná zpráva. Prague: Otevřená společnost.

*Souralová, A. (2008). Lokalita Brno. In I. Kašparová, Š. Ripka, \& K. Sidiropulu Janků (Eds.), Dlouhodobý monitoring situace romských komunit v České republice: Moravské locality (pp. 21-74). Prague: Úřad vlády České republiky, kancelář Rady vlády České republiky pro záležitosti romské komunity.

Stauber, R., \& Vago, R. (Eds.). (2007). The Roma. A minority in Europe. Historical, political and social perspectives. Budapest: CEU Press.

*Straková, J., \& Tomášek, V. (2013). Měření vědomostí a dovedností romských žáků v rámci šetření PISA. Pedagogika, 63(1), 41-53.

*Strobachová, B. (2016). Fenomenologie a empirický výzkum v sociálních vědách [Doctoral dissertation, Masaryk University, Faculty of Education, Brno, Czech Republic]. Retrieved from https: / / is.muni.cz/th/ru8h8/fenomenologie_empirickyvyzkum_textdizertace.pdf

*Svoboda, Z. (2010). Pedagogické etnobrýle aneb tanec mezi hady. In Z. Svobody, P. Morvayová et al., Schola Excludus (pp. 49-89). Ústí nad Labem: Univerzita J. E. Purkyně.

Szalai, J., \& Schiff, C. (Eds.). (2014). Migrant, Roma and post-colonial youth in education across Europe: being "visibly different". Basingstoke: Palgrave Macmillan. 
116 *Šafránková, A. (2014). Vzdělávání sociálně znevýhodněných žáků na úrovni ISCED 1 a 2 [Doctoral dissertation, Palacký University Olomouc, Faculty of Education, Olomouc, Czech Republic]. Retrieved from https://theses.cz/id/mrd2ot/SAFRANKOVA_Anna_disertacni_ prace_autoreferat.pdf

Šišková, T. (2001). Menšiny a migranti v České republice. Prague: Portál.

*Šormová, K. (2016). Jak čtou Romové: Kvantitativní výzkum úrovně čtenářské gramotnosti romských žáků. Prague: Filozofická fakulta Univerzity Karlovy.

*Štěpařová, E. (2009). Sociálně-pedagogické faktory ovlivňující edukaci romských dětí [Doctoral dissertation, Masaryk University, Faculty of Social Education, Brno, Czech Republic]. Retrieved from http://is.muni.cz/th/14754/pedf_d

Trubeta, S. (2013). Roma as homines educandi: A collective subject between educational provision, social control, and humanism. In M. Miskovic. (Ed.), Roma education in Europe. Practices, policies, and politics (pp. 15-28). London: Routledge.

Víšek, P. (1999). Romové v České republice: (1945-1998). Prague: Sociopress.

"Vorličck, R. (2016). Vy jste dole, my nahoře! Lidé Města: Urban People, 18(3), 441-462.

Mgr. Jana Obrovská, Ph.D., Masaryk University, Faculty of Education Poříćí 7, 60300 Brno, Czechia obr@mail.muni.cz

Mgr. Kateřina Sidiropulu Janků, Ph.D. Carinthia University of Applied Sciences, Health Sciences and Social Work Hauptplatz 12, Feldkirchen in Kärnten, 90 500, Austria

K.SidiropuluJanku@cuas.at 